\title{
EPIZOOTICS OF EQUINE INFLUENZA IN CZECHOSLOVAKIA CAUSED BY THE TYPE A/EQUI 2(H3N8), AND THE EFFECTS OF VACCINATION
}

\author{
Z. POSPÍSIL, Bə̀la TƯMOVÁ², L. ULMANN', Dagmar ZENDULKOVÁ \\ and J. FALTEJSEK ${ }^{3}$ \\ Department of Epizootiology, University of Veterinary Science, 61242 Brno, \\ 1 Veterinary Research Institute, 62132 Brno \\ 2 Institute of Hygiene and Epidemiology, 10042 Prague \\ ${ }^{3}$ District Veterinary Office, 53000 Pardubice
}

Received April 17, 1990

\begin{abstract}
Pospíšil Z., Tůmová Běla, Ulmann L., Zendulková Dagmar, Faltejsek J.: Epizootics of Equine Influenza in Czechoslovakia Caused by the Type Alequi 2(H3N8), and the Effects of Vaccination. Acta vet. Brno, 60, 1991: 153-159.

An acute respiratory illness of horses was reported from many parts of Czechoslovakia in the summer of 1989 . Equine influenza virus, identified as the subtype A/equi 2 (H3N8) was isolated from nasal swabs or secrets of affected animals. This is the first report of the occurrence of this subtype in our country. The disease usually passed without subsequent complications and the virus induced formation of specific antibodies in the affected horses. During the epizootics the protective effect of a vaccine prepared in our laboratory was confirmed. Almost none of the vaccinated horses showed any signs of respiratory illness and only mild symptoms developed in the rest.
\end{abstract}

Horses, influenza, epizootics, vaccination, antibody level, protectivity

Similar to the man, influenza outbreaks occur at times also among animals, affecting a significant part of the population. Horses are no exception. Historical records reveal that influenza-like diseases have been occurring all over the Continent from at least as early as the 17th century, but the causal agent was isolated from horses in 1956 only. With some pride we can state that Czech scientists were the first to succeed in the isolation, and this isolate later became a reference strain representing subtype 1 under the designation influenza A/equi 1/56 (H7N7) (Sovinová et al. 1956). Since that time a number of epizootics has been precipitated by the subtype 1 in our country and in the rest of the world (Bla škovič et al. 1966; Túmová et al. 1980; Wood 1988).

In 1963 a second subtype of the equine influenza virus emerged in the U.S.A. (Waddell et al. 1963) and was designated A/equi (Miami) 63. This type has been causing influenza outbreaks all aver the world till the present days ( $T$ úmová 1980). A closer study of both subtypes, abbreviated as $A$ /equi 1 and $A /$ equi 2, respectively, revealed that they can be distinguished by the antigenic structure of their surface antigens - haemagglutinin (HA) and neuraminidase (NA). Conforming with the current nomenclature of influenza viruses, the $A$ /equi 1 and $A$ /equi 2 have capsular antigens of the H7N7 and H3N8 serotypes, respectively (An on 1980, Hin shaw et al. 1983).

The subtype 2 of the equine influenza virus has not been recorded in Czechoslovakia so far. Its occurrence in the neighbouring countries (Eichhorn 1989) and an outbreak of influenza among horses in the late summer 1989 led us to investigate its aetiology and subsequently to identify the causative egent.

\section{Materials and Methods}

1. Herds of horses under study

Three horse herds affected with an acute respiratory illness indicative of an influenza infection were investigated. Of these, the largest was the herd $\mathrm{K}$. totalling 62 horses in training, 70 mares 
and 31 foals. All mares and a part of the trained horses were vaccinated with a polyvalent vaccine against respiratory infections. The clinical course of the disease was recorded and, nasal swabs and blood samples were collected from some animals for virological and serological examinations, respectively.

\section{Collection of material}

Samples of nasal discharge, or, more often, nasal swabs were collected from 25 horses in 3 herds within 3 to 4 days after the onset of clinical disease. In two cases, nasal washings were collected, too. The swabs were put in Eagle MEM medium supplemented with 500 i.u. penicillin, $500 \mu \mathrm{g}$ streptomycin, $400 \mu \mathrm{g}$ gentamycin and $50 \mathrm{u}$. nystatin per $1 \mathrm{ml}$ of the medium and transported in chilled containers to the Institute for laboratory procedures. The antibiotics were also added directly to the nasal discharge samples in the corresponding concentrations.

3. Virological examination

Regarding a well-substantiated suspicion that an influenza virus was the causal agent of the condition, the collected samples were inoculated into allantoic sacs of 9-day-old chick embryos. The rest of the samples, that could not be examined immediately after collection for technical reasons, was frozen to $-70^{\circ} \mathrm{C}$ on dry ice and kept so until examination. The infected chick embryos were incubated for 4 days at $37^{\circ} \mathrm{C}$ and examinated against the light twice a day. The allantoic fluid from dead embryos and from those chilled after 96 hours was collected for laboratory examination and further passage. The haemagglutination tests were carried out either in a macrosystem with volumes of $0.2 \mathrm{ml}$ or a microsystem with $0.05 \mathrm{ml}$ to which equal volumes of a $0.5 \%$ suspension of guinea-pig or chicken erythrocytes were added.

\section{Identification of the isolates}

Haemagglutinating isolates were identified using the haemagglutination inhibition test with specific antisera to the two subtypes of the equine influenza virus, prepared by intranasal immunization of quinea-pigs ( $T$ ůmová et al. 1972, Tủmová et al. 1980).

\section{Serological examination}

The dynamics of antibody formation were investigated using a micromethod of the haemagglutination inhibition test with volumes of $0.025 \mathrm{ml}$ of the tested sera in serial twofold dilutions, to which 4 haemagglutination units of the antigen were added. After $60 \mathrm{~min}$. of incubation, $0.05 \mathrm{ml}$ of $0.5 \%$ suspension of chicken or guinea-pig erythrocytes were added. The results were read after 50 to $60 \mathrm{~min}$. at room temperature. For more details see Anon (1975).

\section{Vaccine}

The polyvalent vaccine against respiratory infections of horses, prepared in the Veterinary Research Institute Brno, is an inactivated adsorbate vaccine containing 2 components administered simultaneously at $4 \mathrm{ml}$ each. The first component contains 2 strains of the equine influenza virus (A/equi 1/Brno and A/equi 2/Fontainebleau), and the equine rhinopenumonitis virus EHV-1. The second component contains capsular antigens of field strains of Rhodococcus equi, Actinobacillus equuli and Streptococcus zooepidemicus (U1 mann et al. 1986).

\section{Results}

\section{Onset and the course of the disease}

An acute respiratory disease of horses was recorded in many parts of Czechoslovakia in late August and early September 1989. The first outbreak was associated with a participation in a horse-race attended by horses from Czechoslovakia and 7 other European countries.

Another race event was held in $\mathrm{H}$. a week later, where some of the horses developed an acute respiratory illness as early as on the first day of their arrival. The disease, accompanied by high body temperature, was of a highly contagious nature, so that a large number of the horses had to be withdrawn during the event because of their illness.

As revealed by the examination of the history, most of the affected horses from all three herds were not protected by vaccination. On the other hand, the vaccinated animals remained normal, or developed only very slight symptoms. 
The dominant symptoms of the disease were general torpidity, weakness, inappetence, and serous and later seromucinous nasal discharge, mostly associated with dry cough. These symptoms were accompanied by elevated body temperatures often exceeding $40^{\circ} \mathrm{C}$. The elevated temperatures persisted for some 3-4 days, then receding for 2 days only to return again for an additional 4-5 days. In this phase, the seriously affected horses were treated with a combination of penicillin and streptomycin, or long-acting penicillin. Most of the symptoms then disappeared and, as the horses were left to rest, their health gradually returned to normal without any further complications.

The vaccinated horses either remained normal, or showed only dry cough and nasal discharge without pyrexia, generalized symptoms being observed exceptionally. Of the total 70 vaccinated mares in the herd $K$., only one showed body temperature exceeding $40^{\circ} \mathrm{C}$, and further 12 ones nasal discharge and cough. On the other hand, mild cough was observed in a half of their foals and sporadic cases of nasal discharge were recorded, too. Similar results were found in the other two herds.

\section{Virus isolation}

None of the examined samples showed a haemagglutination activity in the first passage in chick embryos. However, approximately $85 \%$ of the samples were contaminated with bacteria. Therefore, the allantoic fluid samples were filtered trough millipore filters with foses of $0.22 \mu \mathrm{m}$ in diameter before subsequent passages.

$60 \%$ of the chick embryos died within 72 hours after inoculation in the second passage. Live embryos were chilled down to $+4^{\circ} \mathrm{C}$ and allantoic fluid was collected from all dead and live embryos and examined for haemagglutinating activity. This activity was demonstrated in 9 out of the 25 examined samples with both guinea-pig and chicken erythrocytes. The contaminated material was filtered and all samples were passaged again. The number of samples showing haemagglutinating activity increased to 17 out of the total of 25 examined horses in the third passage.

\section{Virus identification}

It was demonstrated that the isolated strains belonged to the subtype A/equi 2(H3N8). In addition to the reference strain A/equi 2/Miami/63 (H3N8) we also used sera or antigens of this equine influenza subtype, which had been demonstrated in 1976-1980 during epizooties in England, France, Switzerland and Romania, The results listed in Table 1 show that the newly isolated strains already differ to some extent from the strain A/equi $2 / \mathrm{Miami} / 63$, and that this subtype forms drift variants as is the case with the human influenza virus.

\section{Serological examination}

The results of haemagglutination inhibition tests demonstrated that the majority of the non-vaccinated affected horses had no antibodies to either of the subtypes of the A/equi virus (Table 2). A marked increase of the level of antibodies to the A/equi 2 subtype was demostrated, with a further elevation after another 14 days when titres of $1: 40$ to $1: 160$ were recorded in blood sera obtained as early as 14 days after the onset of the disease. On the other hand, no antibodies to the subtype A/equi 1 were demonstrable.

In the majority of the vaccinated horses, the antibody titres to both $\mathrm{A} /$ equi subtypes reached values of $1: 20$ to $1: 40$ in the early stage of the disease, rarely 


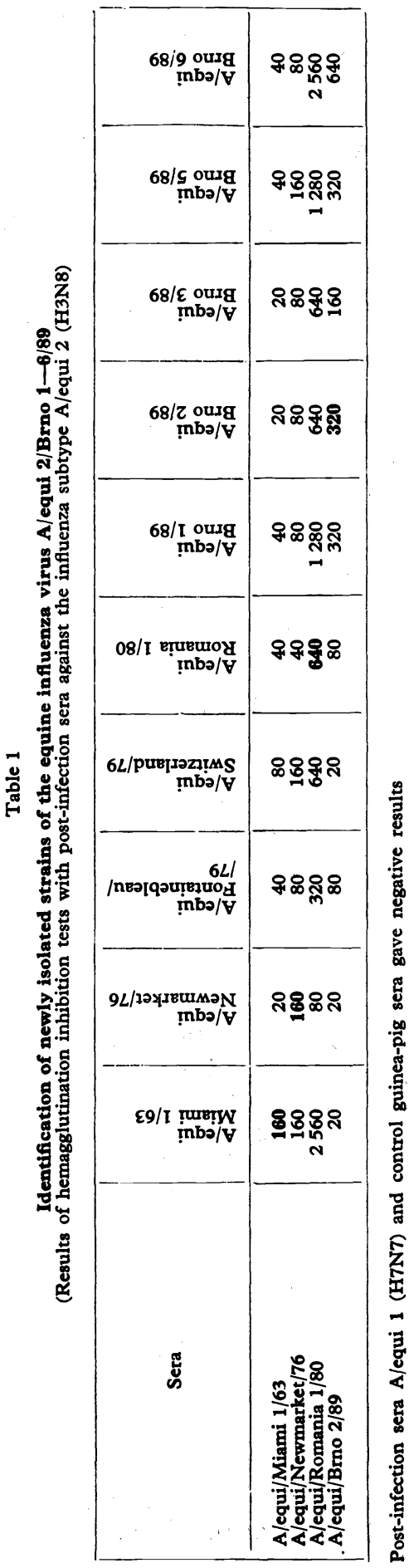

being lower (Table 3). An exception was the horse No. 18 which, although vaccinated, was free of specific antibodies. However, 14 days after the onset of the disease, antibody titre to the subtype A/equi 2 reached a value of $1: 80$ and after 28 days the titre was $1: 160$ in this horse.

No marked changes of antibody levels were observed in a majority of the remaining vaccinated horses. In some cases they persisted at the same level, but more often they rose up by 1 to 2 dilutions for the subtype A/equi 2, rarely rising even higher (Table 3 ). The values obtained for antibodies to the A/equi 1 subtype remained constant over the whole period of investigation.

\section{Discussion}

Our investigations demonstrated for the first time the presence of the equine influenza virus subtype A/equi 2 (H3N8) in horse population in Czechoslovakia. The virus induced typical generalized influenza symptoms with a biphasic pyrexia curve, and a complete recovery.

The aetiological role of the subtype $A$ /equi 2 has been documented by the increase of antibody titres in horse sera collected on days 14 and 28 after the infection, while zero antibody levels against the subtype A/equi 1 persisted over the whole period.

The results of epizootiological observation, isolation experiments and serological examination confirmed the anamnestic data, i.e. that the majority of the affected horses had not been vaccinated. On the other hand, vaccinated horses remained normal, or developed a mild nasal discharge or cough without body temperature elevation and other general symptoms.

An interesting exception among the 86 vaccinated horses. in the herd $\mathrm{K}$. was a horse that became ill as the very first one with rather serious symptoms of a systemic disease. The failure of virus isolation may have resulted from the fact that nasal swabs were taken as late as on day 6 after the onset of the disease. However, a participation of the virus A/equi 2 in its illness was confirmed by the typical increase at the post-infection antibody titre. 
Table 2

Virus isolation and dynamics of antibodies to the subtype $A$ /equi 2 in non-vaceinated horses in the herd $K$

\begin{tabular}{|c|c|c|c|c|c|}
\hline \multirow{2}{*}{ Horse No. } & \multirow{2}{*}{ Disease } & \multirow{2}{*}{$\begin{array}{c}\text { Virus } \\
\text { isolation }\end{array}$} & \multicolumn{3}{|c|}{ Titre of $\mathbf{H I}$ antibodies (A/equi 2) } \\
\hline & & & onset of dis. & day 14 & day 28 \\
\hline $\begin{array}{r}1 \\
2 \\
3 \\
4 \\
5 \\
6 \\
7 \\
8 \\
9 \\
10 \\
11 \\
12 \\
13 \\
14 \\
15 \\
16\end{array}$ & $\begin{array}{l}\text { FD } \\
\text { FD } \\
\text { FD } \\
\text { FD } \\
\text { FD } \\
\text { FD } \\
\text { FD } \\
\text { FD } \\
\text { FD } \\
\text { FD } \\
\text { FD } \\
\text { FD } \\
\text { FD } \\
\text { FD } \\
\text { FD } \\
\text { FD }\end{array}$ & $\begin{array}{c}+ \\
+ \\
+ \\
\text { neg. } \\
+ \\
\text { neg. } \\
\text { neg. } \\
+ \\
+ \\
+ \\
+ \\
+ \\
+ \\
+ \\
+ \\
\text { NT }\end{array}$ & $\begin{array}{c}\text { neg. } \\
\text { neg. } \\
\text { neg. } \\
\text { neg. } \\
\text { neg. } \\
\text { neg. } \\
5 \\
\text { neg. } \\
\text { neg. } \\
\text { neg. } \\
\text { neg. } \\
\text { neg. } \\
\text { neg. } \\
\text { neg. } \\
\text { neg. } \\
5\end{array}$ & $\begin{array}{l}80 \\
40 \\
40 \\
80 \\
20 \\
20 \\
20 \\
40 \\
20 \\
20 \\
20 \\
40 \\
40 \\
20 \\
20 \\
40\end{array}$ & $\begin{array}{r}160 \\
80 \\
80 \\
80 \\
80 \\
40 \\
40 \\
80 \\
40 \\
40 \\
40 \\
80 \\
160 \\
40 \\
20 \\
40\end{array}$ \\
\hline
\end{tabular}

$+\quad=$ isolation of the virus $\mathrm{A} /$ equi $2 / \mathrm{Brno} / 89$

FD = full development of the disease

$\mathrm{NT}=$ not tested

Table 3

Virus isolation and dynamics of antibodies to the subtype $A$ /equi 2 in vaccinated horses in the herd $K$

\begin{tabular}{|c|c|c|c|c|c|}
\hline \multirow{2}{*}{ Horse No. } & \multirow{2}{*}{ Disease } & \multirow{2}{*}{$\begin{array}{l}\text { Virus } \\
\text { isolation }\end{array}$} & \multicolumn{3}{|c|}{ Titre of $\mathrm{HI}$ antibodies (A'equi 2) } \\
\hline & & & onset of dis. & day 14 & day 28 \\
\hline $\begin{array}{l}17 \\
18 \\
\\
\\
19 \\
20 \\
21 \\
22 \\
23 \\
24 \\
25 \\
26 \\
27 \\
28 \\
29 \\
30 \\
31 \\
32\end{array}$ & $\begin{array}{c}\text { ND } \\
\text { FD } \\
\text { first horse of the } \\
\text { whole yard to be- } \\
\text { come affected } \\
\text { ND } \\
\text { H } \\
\text { H } \\
\text { H } \\
\text { H } \\
\text { H } \\
\text { H } \\
\text { C, } \mathbf{N D} \\
\text { H } \\
\text { C, } \mathrm{ND}\end{array}$ & $\begin{array}{l}+ \\
\text { neg. } \\
\\
\text { neg. } \\
\text { NT } \\
\text { NT } \\
\text { NT } \\
\text { NT } \\
\text { NT } \\
\text { NT } \\
\text { NT } \\
\text { NT } \\
\text { NT } \\
+ \\
\text { NT } \\
\text { NT } \\
\text { neg. }\end{array}$ & $\begin{array}{l}20 \\
40 \\
20 \\
20 \\
20 \\
40 \\
40 \\
40 \\
20 \\
20 \\
10 \\
20 \\
40 \\
20\end{array}$ & $\begin{array}{r}40 \\
160 \\
80 \\
40 \\
20 \\
40 \\
40 \\
40 \\
40 \\
20 \\
20 \\
80 \\
40 \\
80\end{array}$ & $\begin{array}{r}320 \\
160 \\
\\
\\
80 \\
160 \\
80 \\
40 \\
40 \\
40 \\
40 \\
40 \\
40 \\
40 \\
80 \\
20 \\
80 \\
160\end{array}$ \\
\hline
\end{tabular}

$+\quad=$ isolation of the virus A/equi $2 / \mathrm{Brno} / 89$

$\mathrm{FD}=$ full development of the disease

$\mathrm{ND}=$ nasal discharge

$\mathrm{C}=$ cough

$\mathrm{H}=$ healthy

$\mathrm{NT}=$ not tested

In the vaccinated horses, antibody titres against the subtype $\mathrm{A} /$ equi 1 remained at the same level over the whole period of observation, but those against the subtype A/ equi 2 rose by 1 to 2 dilutions in many cases and sporadically even higher. This provides a clear evidence of a contact of the animals with the virus or of a mild infection having taken place either without clinical signs or being accompanied only by a mild cough and nasal discharge.

Monitoring humoral immunity provides data representing only one of the components of defense mechanisms participating in post-infectious processes of the 
organism. Therefore, it is difficult to determine the levels of antibodies which would still impart protective effects. However, it can be inferred from our observation of the vaccinated horses that the levels of haemagglutination inhibiting antibody titres of $1: 20$ to $1: 40$ already conferred certain degree of protection against natural infection with the influenza virus. Similar.conclusions were drawn by Fontaine and Moraillon (1980), who observed only mild clinical symptoms in horses with antibody titres below $1: 20$ and a full development of the disease in those with titres up to $1: 10$, while horses with titres between $1: 20$ and $1: 40$ were protected against the infection. At the same time, however, the authors point out that not all vaccines developed so far can prevent outbreaks of influenza. A different approach to evaluating protective levels against experimental infection with the influenza virus was attempted by Mumford et al.(1988) who, from the results of simple radial haemolysis, concluded that fully protected are horses with antibody levels over $74 \mathrm{~mm}^{3}$.

Our epizootiological and serological examinations confirmed a good protective effect of the vaccine prepared in our laboratory. The importance of vaccination in the control of equine influenza was also stressed by Swedish authors (Klingeborn et al. 1980) who investigated a group of more than 1300 horses and found that $98 \%, 75 \%$ and $37 \%$ of the non-vaccinated, singly vaccinated and repeatedly vaccinated horses, respectively, were affected with influenza. However, Cullinane (1989) warned that vaccinated horses with low antibody levels may become a dangerous source of infection, shedding the virus without any clinical signs of the disease.

In spite of several drawbacks vaccination of horses with combined vaccines against respiratory infections has been recommended worldwide and is often implemented. As the conferred imunity rarely exceeds 6 months (T ůmová et al. 1972; Eichhorn 1989), regular revaccination programmes are recommended. They are necessary especially if horses are often transported to various sports events or come otherwise in frequent contact with groups of other horses, i. e. where the risk of any outbreak of any infection is high.

\section{Epizootie influenzy koní v Československu vyvolaná virem A/equi (H3N8) a vliv vakcinace na průběh onemocnění}

Bylo popsáno akutní respirační onemocnění koní, které proběhlo $\mathrm{v}$ mnoha oblastech Československa v létě 1989 . Z nosních výtěrů nebo sekretu nemocných zviřat byl izolován virus influenzy koní, určený při bližší typizaci jako subtyp A/equi 2 (H3N8). Jedná se o první výskyt tohoto subtypu na našem území. Onemocnění odeznělo většinou bez následných komplikací a virus vyvolal u nemocných koní tvorbu specifických postinfekčních protilátek. $\mathrm{V}$ průběhu epizootie byl potvrzen ochranný účinek námi připravené vakcíny - vakcinovaní koně většinou neonemocněli, v ojedinělých př́ipadech onemocnění byl průběh infekce jen velmi mírný.

\section{Эпизоотия гриппа пошадей в Чехословакии, вызванная вирүсом A/equi /H3N8/ и влияние вакцинации на протекание заболевания}

Приводилось описание острого заболевания дыхательных пүтей лошадей, имевшехо место во многих областях Чехословакии летом 1989 года. Из мазков носа или выделений больных животных изолировали 
вирус гриппа лошадей, при более точной типизации определенный в качестве подтипа A/equi 2 (H3N8). Речь идет о первом наличии данного подтипа на нашей территории. Заболевание большей частью прошло без последующих осложнений и вирус у больных лошадей вызвал образование специфических послеинфекционных антител. В ходе эпизоотии было подтверждено защитное воздействие подготовленой нами вакцины - вакцинированные лошади в боляшинстве случаев не болели, в отдельных случаях процесс инфекции проходил весьма умерено.

\section{References}

ANON: Advanced laboratory techniques for influenza virus. Immunology Series No 6. Procedural Guide 1975. U.S.Dept. Health, Atlanta

ANON: A revision of the system of nomenclature for influenza viruses: A WHO memorandum. Bull. Wld. Hlth. Org., 58, 1980: 585-591

BLAŠKOVIČ, D.-SZANTO, J.-KAPITÁNČIK, B.-LEŠŠ, J.-LACKOVIČ, V.SKARDA, R.: Experimental pathogenesis of A/equi 1 influenza in horses. Acta virol., 10, 1966: $513-520$

CULLINANE, A.: Equine influenza - an update. Irish vet. J., 42, 1989: 98-99

EICHHORN, W.: Respiratorische Infektionskrankheiten beim Pferd. Prakt. Tierärtz., 44, 1989: $37-45$

FONTAINE, M.-MORAILLON, A.: Considérations sur l'epizootie de grippe 1978-1979 en France. Rec. Méd. vét., 156, 1980: 139-145

HINSHAW, V. S. - NAEVE, C. W.-WEBSTER, R. G. -DOUGLAS, A. - SKEHEL, J.J. a BRYANS, J.: Analysis of antigenic variation in equine 2 influenza A viruses. Bull. Wld. Hlth. Org., 62, 1983: 153-158

KLINGEBORN, B.-ROCKBORN, G.-DINTER, Z.: Significant antigenic drift with the influenza equi 2 subtype in Sweden. Vet. Rec., 106, 1980: $363-364$

MUMFORD, J. A. - WOOD, J. M.-FOLKERS, C.-SCHILD, G. C.: Protection against experimental infection with influenza virus A/equine/Miami/63(H3N8) provided by inactivated whole virus vaccines containing homologous virus. Epid. and Inf., 100, 1988: 501 - 510

SOVINOVÁ, C.-TƯMOVÁ, B.-POUSTKA, F.-NEMEC, J.: Isolation of virus causing respiratory disease of horses. Acta virol., 2, 1958: 52-61

TŮMOVÁ, B.: Equine influenza - a segment in influenza virus ecology. Comp. Immunol., Microbiol., Inf. Dis., 3, 1980: 45-59.

TƯMOVA, B. - EASTERDAY, B. C. - ṠTUMPA, A.: Simultaneous occurrence of A/equi 1 and $\mathrm{A} /$ equi 2 influenza viruses in a small group of horses. Amer. J. Epidem., 95, 1972: 80-87

TÚMA, B.-ŠTUMPA, A.-ZAKOPAL, J. - VĚŽNfKOVÁ, D. - MENŠfK, J.: Persistence in nature of influenza virus A/equi/Praha/56 (Heq 1 Neq 1). Acta virol., 24, 1980: 63-67

ULMANN, L. - JURÁK,E. - VĚŽNIKOVA, D. - VALOŠKOVÁ P. - FALTEJSEK, J.: Komplexni ochrana hřibat před respiračnin:i infekcemi. Project report, Veterinary Research Institute Brno, 1986, 30 p.

WADDELL, G. H.-THEIGHLAND. M. B.-SIEGEL, M. M.: A new influenza virus associated with equine respiratory disease. J. Am. vet. med. Ass., 143, 1963: 587-590

WOOD, J. M.: Antigenic variation of equine influenza: a stable virus. Equine vet. J., 20, 1988: $316-318$ 